Diabetologia $10,237-243(\mathbf{1 9 7 4})$

(C) by Springer-Verlag 1974

\title{
Plasma Insulin in Minor Abnormalities of Glucose Tolerance: a 5 Year Follow-Up
}

\author{
W.T. Strauss and C.N. Hales \\ Arbroath Infirmary, University of St. Andrews, and Department of Medical Biochemistry, The Welsh National School \\ of Medicine
}

Received: September, 21, 1973, and in revised form: March 5, 1974

\begin{abstract}
Summary. Blood glucose and plasma insulin concentrations have been measured in the fasting state and 15,30 , $45,60,90$ and $120 \mathrm{~min}$ after $50 \mathrm{~g}$ glucose administered orally to subjects tested in a similar manner 5 years previously. - As a result of the previous test the subjects had been divided into three groups: Group I - normal glucose tolerance, no glucosuria; Group II - normal glucose tolerance and glucosuria; Group III - normal fasting blood sugar concentration, but a failure of the blood sugar to return to the fasting level up to $120 \mathrm{~min}$ after glucose. - None of the subjects previously classified as normal (Group I), but three (all previously obese) of Group II and five (three previously obese) of Group III had become diabetic. - There was an increasing tendency to loss of weight the worse the glucose tolerance. For all subjects the weight change and change in the $120 \mathrm{~min}$ blood glucose
\end{abstract}

concentration gave a correlation coefficient of -0.47 $(p<0.01)$. Group III subjects previously of normal weight gained weight $(p<0.02)$. - It was concluded that obese subjects with defective initial rises in plasma insulin concentration following oral glucose were those most likely to develop diabetes. Some obese subjects with normal glucose tolerance, glucosuria and apparently normal early insulin rise were also prediabetic. - The results suggested that in the former, but not the latter subjects, continued deterioration of the early insulin response was a factor in the emergence of diabetes, but due to the small numbers of subjects no definite conclusion could be reached on this point.

Key words: Blood glucose, plasma insulin, prediabetes, diabetes, prospective survey, weight change.
The changes in insulin release in response to oral glucose which precede the onset of diabetes remain controversial. A reduced and delayed release has been described in clinical diabetes [14], subclinical diabetes [11] and in "prediabetes" [2]. However, the characterisation of subjects with a strong family history of diabetes, particularly when this relates to an identical twin, as prediabetic has been questioned $[10,13]$. Tattersall and Pyke [13] have concluded that the demonstration of defective insulin secretion in the unaffected twin of a diabetic cannot be assumed to indicate that this is an early feature of diabetes without a follow up study showing the development of diabetes. Other workers [6] have found increased insulin responses to oral glucose in genetically determined potential diabeties. Few investigations have attempted to define the role of changes in plasma insulin in the onset of diabetes by following individuals from a stage of normal glucose tolerance to a later stage of frank diabetes. As a result of largely chance observations a limited number of subjects have been described with normal insulin responses to oral glucose prior to the onset of diabetes $[4,3]$. Danowski et al. [3] found that in three of four subjects the insulin response increased when diabetes occurred. Johansen [7] reported a case in which the insulin response fell with deterioration of glucose tolerance, whilst Fajans et al. [8] have found no consistent relationship between changes in plasma insulin response and changes in glucose tolerance.

In a previous study [5] the plasma insulin response was measured after $50 \mathrm{~g}$ glucose administered orally to three groups of subjects taken from the population of
Arbroath: Group I - normal glucose tolerance, no glucosuria; Group II - normal glucose tolerance and glucosuria; Group III - normal fasting blood sugar concentration, but a failure of the blood sugar to return to the fasting level up to $120 \mathrm{~min}$ after glucose. The blood glucose and plasma insulin concentrations observed in Group II were characterised by an exaggerated early rise and a tendency to late hypoglycaemia. The non-obese subjects of Group III showed a delay in the rise of plasma insulin concentration. In order to assess the relevance of these findings to the aetiology of diabetes mellitus, a repeat of this study has been carried out on the same individuals after an interval of 5 years.

\section{Methods}

Tests on People of Arbroath. In 1969-70 an attempt was made to trace and retest all the individuals tested in 1964-65, [5]. The $50 \mathrm{~g}$ oral glucose tolerance tests were then carried out after an overnight stay in hospital and before rising. This was a modification of the 1964-65 tests, which were carried out on ambulant subjects rested for $30 \mathrm{~min}$ in the out-patient clinic. Venous blood samples were taken for the determination of glucose and insulin. None of the subjects had been treated either by diet or drugs as a result of their previous glucose tolerance and all were on a normal diet containing more than $200 \mathrm{~g}$ of carbohydrate.

Plasma Samples. Blood was taken from an antecubital vein. Two samples were taken fasting at an 
interval of five minutes prior to the administration of glucose; then single samples were taken $15,30,45,60$, 90 and $120 \mathrm{~min}$. Glucose samples were processed and stored as previously [5].

Blood or Plasma Estimations. Blood glucose and plasma insulin were measured as previously described [5]. retested, had become diabetic, or died by the 1969-70 investigation. The precise numbers, mean age, sex ratio, mean \% ideal weight and mean concentration of blood glucose and plasma insulin in 1964-65 of those retested are compared with the relevant figures for the whole population tested in 1964-65 in Table 2. From this it may be seen that the sample of the original study

Table 1. Recovery of subjects originally investigated in 1964-65 in the 5 year follow up investigation

\begin{tabular}{|c|c|c|c|c|c|}
\hline \multicolumn{2}{|l|}{$1964-1965$} & \multicolumn{3}{|l|}{$1969-1970$} & \multirow[b]{2}{*}{ Cause of death } \\
\hline Group & Number & $\begin{array}{l}\text { Retested or } \\
\text { diabetic }\end{array}$ & Did not attend & Deaths & \\
\hline $\begin{array}{l}\text { I } \\
\text { Normal }\end{array}$ & 27 & 16 & 9 & 2 & 1 coronary; 1 pulmonary embolism \\
\hline $\begin{array}{l}\text { II } \\
\text { Normal } \\
\text { Glucosuric }\end{array}$ & 25 & 16 & 6 & 3 & 3 coronaries \\
\hline $\begin{array}{l}\text { III } \\
\text { Delayed Return }\end{array}$ & 26 & 12 & 9 & 5 & $\begin{array}{l}1 \text { coronary; } 1 \text { carcinoma stomach, } \\
3 \text { unknown }\end{array}$ \\
\hline Total & 78 & 44 & 24 & 10 & \\
\hline
\end{tabular}

Table 2. Comparison of mean results of GTT's in all subjects in the 1964-65 study with mean results in 1964-65 (in italics) of those subjects who were retested in 1969-70

\begin{tabular}{|c|c|c|c|c|c|c|c|c|c|c|}
\hline \multirow[t]{2}{*}{ Group } & \multirow{2}{*}{$\begin{array}{l}\text { No. of } \\
\text { people }\end{array}$} & \multirow{2}{*}{$\begin{array}{l}\text { Mean } \\
\text { Age } \\
\text { (yr.) }\end{array}$} & \multirow{2}{*}{$\begin{array}{l}\text { Sex } \\
(\mathbf{M}: \mathbf{F})\end{array}$} & \multirow{2}{*}{$\begin{array}{l}\text { Mean \% } \\
\text { ideal } \\
\text { weight }\end{array}$} & \multirow[t]{2}{*}{ Substance measured } & \multicolumn{5}{|c|}{$\begin{array}{l}\text { Concentration and time after glucose ad- } \\
\text { ministration }\end{array}$} \\
\hline & & & & & & $\begin{array}{l}0 \\
\min \end{array}$ & $\begin{array}{ll}30 \\
\min \end{array}$ & $\begin{array}{l}60 \\
\min \end{array}$ & $\begin{array}{l}90 \\
\min \end{array}$ & $\begin{array}{l}120 \\
\min \end{array}$ \\
\hline $\begin{array}{l}\text { Normal } \\
\text { non-obese }\end{array}$ & 14 & 42 & $10: 4$ & 98 & $\begin{array}{l}\text { Blood glucose } \\
\text { (mg per } 100 \mathrm{ml} \text { ) } \\
\text { Plasma insulin } \\
\text { (micro units per ml) }\end{array}$ & $\begin{array}{l}65 \\
66 \\
20 \\
19\end{array}$ & $\begin{array}{l}91 \\
92 \\
55 \\
57\end{array}$ & $\begin{array}{l}72 \\
74 \\
44 \\
36\end{array}$ & $\begin{array}{l}60 \\
62 \\
33 \\
24\end{array}$ & $\begin{array}{l}58 \\
61 \\
25 \\
26\end{array}$ \\
\hline $\begin{array}{l}\text { Normal } \\
\text { obese }\end{array}$ & 13 & 48 & $10: 3$ & 122 & $\begin{array}{l}\text { Blood glucose } \\
\text { (mg } 100 \text { ml) } \\
\text { Plasma insulin } \\
\text { (micro units per ml) }\end{array}$ & $\begin{array}{l}68 \\
67 \\
27 \\
26\end{array}$ & $\begin{array}{r}106 \\
111 \\
74 \\
72\end{array}$ & $\begin{array}{l}92 \\
78 \\
65 \\
63\end{array}$ & $\begin{array}{l}83 \\
76 \\
58 \\
45\end{array}$ & $\begin{array}{l}63 \\
65 \\
38 \\
34\end{array}$ \\
\hline $\begin{array}{l}\text { Normal } \\
\text { glucosuric } \\
\text { non-obese }\end{array}$ & 10 & 47 & $10: 0$ & 101 & $\begin{array}{l}\text { Blood glucose } \\
\text { (mg per } 100 \mathrm{ml} \text { ) } \\
\text { Plasma insulin } \\
\text { (micro units per ml) }\end{array}$ & $\begin{array}{l}66 \\
67 \\
27 \\
28\end{array}$ & $\begin{array}{r}108 \\
107 \\
88 \\
105\end{array}$ & $\begin{array}{l}84 \\
83 \\
72 \\
88\end{array}$ & $\begin{array}{l}60 \\
53 \\
42 \\
44\end{array}$ & $\begin{array}{l}49 \\
46 \\
31 \\
34\end{array}$ \\
\hline $\begin{array}{l}\text { Normal } \\
\text { glucosuric } \\
\text { obese }\end{array}$ & 15 & 47 & $\begin{array}{l}15: 0 \\
10: 0\end{array}$ & $\begin{array}{l}127 \\
128\end{array}$ & $\begin{array}{l}\text { Blood glucose } \\
\text { (mg per } 100 \mathrm{ml} \text { ) } \\
\text { Plasma insulin } \\
\text { (micro units per ml) }\end{array}$ & $\begin{array}{l}67 \\
66 \\
28 \\
30\end{array}$ & $\begin{array}{r}108 \\
112 \\
89 \\
94\end{array}$ & $\begin{array}{r}112 \\
113 \\
94 \\
99\end{array}$ & $\begin{array}{l}78 \\
79 \\
64 \\
68\end{array}$ & $\begin{array}{l}58 \\
57 \\
32 \\
30\end{array}$ \\
\hline $\begin{array}{l}\text { Delayed } \\
\text { return } \\
\text { non-obese }\end{array}$ & 14 & 36 & $3: 5$ & 96 & $\begin{array}{l}\text { Blood glucose } \\
\text { (mg per } 100 \mathrm{ml} \text { ) } \\
\text { Plasma insulin } \\
\text { (micro units per ml) }\end{array}$ & $\begin{array}{l}66 \\
68 \\
18 \\
20\end{array}$ & $\begin{array}{r}104 \\
110 \\
42 \\
41\end{array}$ & $\begin{array}{r}117 \\
114 \\
46 \\
42\end{array}$ & $\begin{array}{r}107 \\
102 \\
48 \\
40\end{array}$ & $\begin{array}{l}93 \\
90 \\
42 \\
34\end{array}$ \\
\hline $\begin{array}{l}\text { Delayed } \\
\text { return } \\
\text { obese }\end{array}$ & $\begin{array}{r}12 \\
4\end{array}$ & 58 & $1: 3$ & 124 & $\begin{array}{l}\text { Blood glucose } \\
\text { (mg per } 100 \mathrm{ml} \text { ) } \\
\text { Plasma insulin } \\
\text { (micro units per } \mathrm{ml} \text { ) }\end{array}$ & $\begin{array}{l}62 \\
64 \\
28 \\
26\end{array}$ & $\begin{array}{r}112 \\
117 \\
61 \\
50\end{array}$ & $\begin{array}{r}111 \\
116 \\
61 \\
62\end{array}$ & $\begin{array}{r}103 \\
716 \\
57 \\
87\end{array}$ & $\begin{array}{l}89 \\
89 \\
56 \\
69\end{array}$ \\
\hline
\end{tabular}

\section{Results}

Recovery Subjects. Table 1 shows the number and distribution of subjects attending the 1964-65 and 1969-70 investigations and the number and causes of deaths. $69 \%$ of the subjects tested in 1964-65 were which was available for retesting in 1969-70 was reasonably representative of the population studied in 1964-65. As in the previous study, all the normal glucosuric subjects were male. No effect of sex on the results of glucose tolerance and changes in insulin concentration were detected previously. Much larger 
groups of subjects would be required to determine whether sex influenced the degree and type of change observed over the five year period of this study.

Changes after 5 Years: Glucose Tolerance. Fig. 1 shows the mean blood glucose and plasma insulin concentrations of the individuals tested both in 1964-65 and 1969-70, divided into obese and non-obese subjects and groups according to their classification in 1964-65. The statistical analysis of these results is presented in Table 3. On average, all the glucose tolerances had become worse over the 5 year period as judged by absolute values and in relation to the time taken to return to the fasting level. The tendency was most marked in previously obese subjects with "delayed return". The fasting blood glucose concentration had increased in all groups, the increases ranging from $8 \mathrm{mg} / 100 \mathrm{ml}$ in the normal non-obese to $26 \mathrm{mg} / 100 \mathrm{in}$ the delayed return, obese group. Although the blood glucose was measured by the same method on both occasions, it is impossible to rule out the occurrence of

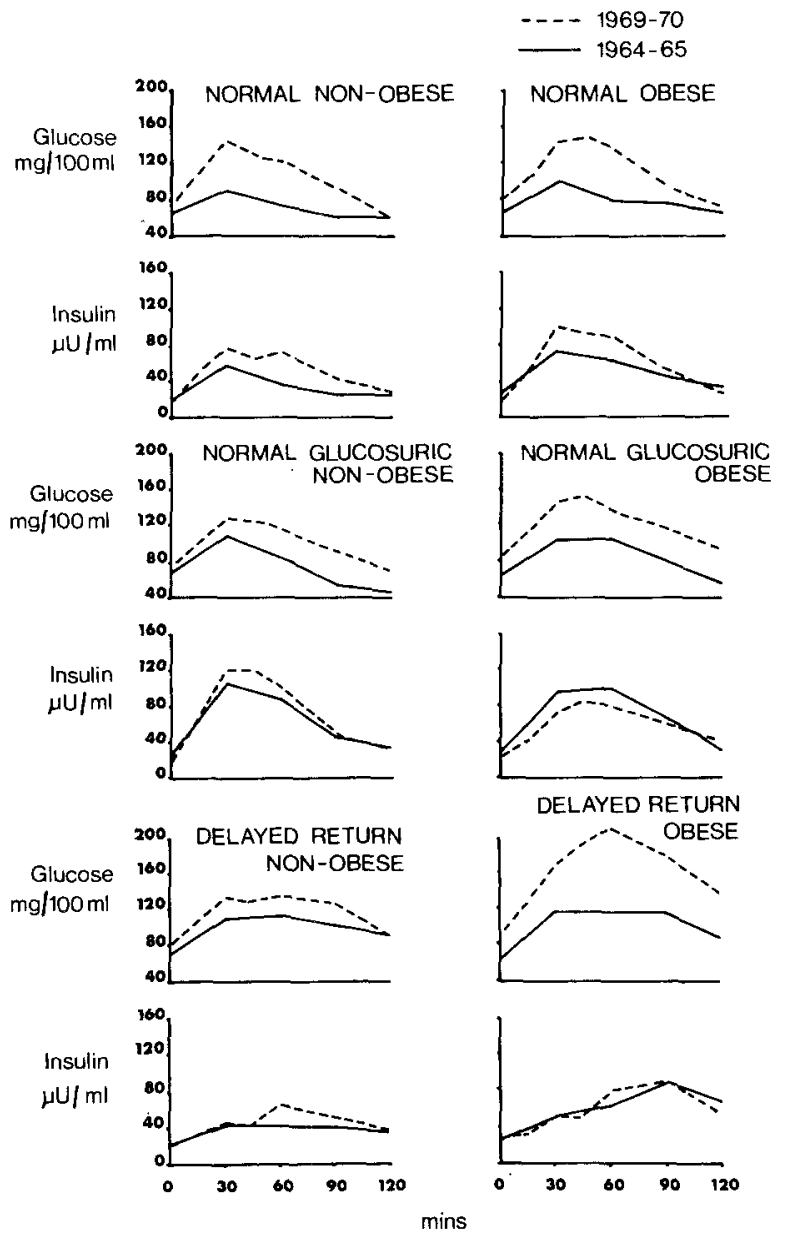

Fig. 1. Mean blood glucose and plasma insulin concentrations during $50 \mathrm{~g}$ oral glucose tolerance tests carried out in 1964-65 compared with the results of similar tests carried out in the same individuals in 1969-70. The statistical analysis of the results is given in Table 3 a small, systematic difference in the estimation of blood glucose between the two studies. The reasons for believing that the increases in blood glucose were mainly if not entirely accounted for by a deterioration of glucose tolerance were as follows: the increases in fasting glucose were not uniform, but least in the normal and most in the delayed return groups and were greater in the obese than the non-obese in all groups; glucose tolerance is known to deteriorate with increasing age; the shape of the glucose tolerance curve with closely parallel increases in insulin concentration are further evidence that glucose tolerance had deteriorated even in the normal, non-obese group. The degree of deterioration of glucose tolerance has been assessed in three different ways: production of "diabetes" according to various criteria (Table 4): increase in the area under the glucose curve and increase in the $120 \mathrm{~min}$ glucose concentration. Taking the first three most stringent criteria as indicating diabetes (clinical diabetes; blood glucose concentration at $120 \mathrm{~min}>120 \mathrm{mg} / \mathrm{ml}$ and either or both the concentrations at $90 \mathrm{~min}>140 \mathrm{mg} /$ $100 \mathrm{ml}$ and at $60 \mathrm{~min}>160 \mathrm{mg} / 100 \mathrm{ml}$ ) none of the subjects classified as normal in. 1964-65 had become diabetic, but three (all previously obese) classified as delayed return had done so. The complete analysis of the transitions in classification which occurred between the two studies is shown in Fig. 2. The deterioration in glucose tolerance expressed either as increase in the area under the glucose curve or as increase in the $120 \mathrm{~min}$ blood ghucose concentration is given in Table 5 . Most of the groups showed a significant increase in the area under the glucose curve, but there was no significant increase in the $120 \mathrm{~min}$ blood glucose concentration in the normal groups.

Weight. The mean weight changes which occurred over the five year period between the two investigations are shown in Fig. 3. Of the subjects who were obese (1964-65) both the normal glucosuric and delayed return groups, on average, lost weight to a significant degree $(p<0.05)$. The only other significant mean weight change recorded was in the non-obese subjects with delayed return, who gained weight $(p<$ $0.02)$.

Plasma Insulin. In parallel with the higher and more prolonged elevation of the glucose tolerance curve in 1969-70 the obese and non-obese subjects who were normal in 1964-65 showed higher and more prolonged elevations of plasma insulin concentration in 1969-70. The area under the insulin curve was significantly increased in the non-obese $(p<0.001)$ and obese $(p<$ 0.025 ) groups and the $30 \mathrm{~min}$ insulin concentration was significantly raised in the non-obese group $(p<0.05)$. The non-obese subjects who were 'normal glucosuric' in 1964-65 continued to show a rapid high rise in plasma insulin in 1969-70, whereas the members of this group who were obese in 1964-65 no longer showed a rise in excess of the normal obese subjects. The response of the latter had increased, whilst that of the former had, if anything, slightly decreased. There was little change 
Table 3. Comparison of results ${ }^{1}$ of GTT's in 1964-65 with those of same subjects tested in 1969-70 (in italics)

\begin{tabular}{|c|c|c|c|c|c|c|c|c|c|}
\hline \multirow{2}{*}{ Group } & \multirow{2}{*}{$\begin{array}{l}\text { No. of } \\
\text { People }\end{array}$} & \multirow{2}{*}{$\begin{array}{l}\text { Substance } \\
\text { measured }\end{array}$} & \multicolumn{7}{|c|}{ Concentration and time after glucose administration } \\
\hline & & & $\begin{array}{l}0 \\
\min \end{array}$ & $\begin{array}{l}15 \\
\min \end{array}$ & $\begin{array}{l}30 \\
\min \end{array}$ & $\begin{array}{l}45 \\
\min \end{array}$ & $\begin{array}{l}60 \\
\min \end{array}$ & $\begin{array}{l}90 \\
\min \end{array}$ & $\begin{array}{l}120 \\
\min \end{array}$ \\
\hline $\begin{array}{l}\text { Normal } \\
\text { non-obese }\end{array}$ & 8 & $\begin{array}{l}\text { Blood glucose } \\
\text { (mg per } 100 \mathrm{ml} \text { ) } \\
\text { Plasma insulin } \\
\text { (microunits per ml) }\end{array}$ & $\begin{array}{l}66 \pm 3 \\
74 \pm 2^{a} \\
19 \pm 2 \\
17 \pm 1\end{array}$ & $\begin{array}{r}109 \pm 7 \\
50 \pm 7\end{array}$ & $\begin{array}{l}92 \pm 6 \\
144 \pm 10^{\mathrm{b}} \\
57 \pm 9 \\
76 \pm 12\end{array}$ & $\begin{array}{c}131 \pm 11 \\
64 \pm 9\end{array}$ & $\begin{array}{l}74 \pm 5 \\
123 \pm 14^{\mathrm{b}} \\
36 \pm 5 \\
72 \pm 10^{\mathrm{b}}\end{array}$ & $\begin{array}{l}62 \pm 6 \\
93 \pm 13 \\
24 \pm 4 \\
42 \pm 9\end{array}$ & $\begin{array}{l}61 \pm 4 \\
59 \pm 5 \\
26 \pm 5 \\
28 \pm 5\end{array}$ \\
\hline $\begin{array}{l}\text { Normal } \\
\text { obese }\end{array}$ & 8 & $\begin{array}{l}\text { Blood glucose } \\
\text { (mg per } 100 \mathrm{ml} \text { ) } \\
\text { Plasma insulin } \\
\text { (microunits per ml) }\end{array}$ & $\begin{array}{l}67 \pm 2 \\
81 \pm 2^{\mathrm{c}} \\
26 \pm 8 \\
18 \pm 2\end{array}$ & $\begin{array}{r}106 \pm 6 \\
54 \pm 6\end{array}$ & $\begin{array}{l}111 \pm 4 \\
143 \pm 10^{a} \\
72 \pm 8 \\
99 \pm 18\end{array}$ & $\begin{array}{r}147 \pm 10 \\
92 \pm 10\end{array}$ & $\begin{array}{c}78 \pm 4 \\
735 \pm 12^{b} \\
63 \pm 10 \\
89 \pm 13\end{array}$ & $\begin{array}{l}76 \pm 3 \\
94 \pm 11 \\
45 \pm 6 \\
52 \pm 8\end{array}$ & $\begin{array}{l}65 \pm 1 \\
69 \pm 7 \\
34 \pm 6 \\
27 \pm 2\end{array}$ \\
\hline $\begin{array}{l}\text { Normal } \\
\text { glucosuric } \\
\text { non-obese }\end{array}$ & 6 & $\begin{array}{l}\text { Blood glucose } \\
\text { (mg per } 100 \mathrm{ml} \text { ) } \\
\text { Plasma insulin } \\
\text { (microunits per ml) }\end{array}$ & $\begin{array}{l}67 \pm 3 \\
76 \pm 2^{\mathrm{a}} \\
28 \pm \mathbf{3} \\
19 \pm \mathbf{3}\end{array}$ & $\begin{array}{l}99 \pm 7 \\
67 \pm \mathbf{3 3}\end{array}$ & $\begin{array}{l}107 \pm 8 \\
127 \pm 8 \\
105 \pm 28 \\
119 \pm 47\end{array}$ & $\begin{array}{l}124 \pm 13 \\
120 \pm 48\end{array}$ & $\begin{array}{c}83 \pm 8 \\
115 \pm 12 \\
88 \pm 16 \\
103 \pm 39\end{array}$ & $\begin{array}{l}53 \pm 4 \\
90 \pm 10^{\mathrm{a}} \\
44 \pm 6 \\
51 \pm 11\end{array}$ & $\begin{array}{l}46 \pm 5 \\
69 \pm 7 a \\
34 \pm 3 \\
31 \pm 8\end{array}$ \\
\hline $\begin{array}{l}\text { Normal } \\
\text { glucosuric } \\
\text { obese }\end{array}$ & 10 & $\begin{array}{l}\text { Blood glucose } \\
\text { (mg per } 100 \mathrm{ml} \text { ) } \\
\text { Plasma insulin } \\
\text { (microunits per ml) }\end{array}$ & $\begin{array}{l}66 \pm 3 \\
85 \pm 3 \mathbf{b} \\
30 \pm 4 \\
21 \pm 2\end{array}$ & $\begin{array}{r}111 \pm 8 \\
42 \pm 6\end{array}$ & $\begin{array}{l}112 \pm 7 \\
143 \pm 12 \mathrm{a} \\
94 \pm 13 \\
72 \pm 13\end{array}$ & $\begin{array}{l}151 \pm 15 \\
84 \pm 21\end{array}$ & $\begin{array}{r}113 \pm 7 \\
137 \pm 11 \\
99 \pm 12 \\
79 \pm 17\end{array}$ & $\begin{array}{l}79 \pm 7 \\
116 \pm 10^{\mathrm{a}} \\
68 \pm 14 \\
61 \pm 7\end{array}$ & $\begin{array}{l}57 \pm 5 \\
92 \pm 10^{b} \\
30 \pm 4 \\
41 \pm 7\end{array}$ \\
\hline $\begin{array}{l}\text { Delayed } \\
\text { return } \\
\text { non-obese }\end{array}$ & 8 & $\begin{array}{l}\text { Blood glucose } \\
\text { (mg per } 100 \mathrm{ml} \text { ) } \\
\text { Plasma insulin } \\
\text { (microunits per ml) }\end{array}$ & $\begin{array}{l}68 \pm 2 \\
81 \pm 4^{\mathrm{a}} \\
20 \pm \mathbf{3} \\
19 \pm 2\end{array}$ & $\begin{array}{l}707 \pm 7 \\
32 \pm 5\end{array}$ & $\begin{array}{l}110 \pm 5 \\
133 \pm 8^{a} \\
41 \pm 4 \\
45 \pm 4\end{array}$ & $\begin{array}{c}129 \pm 10 \\
41 \pm 8\end{array}$ & $\begin{array}{l}114 \pm 9 \\
136 \pm 14 \\
42 \pm 5 \\
64 \pm 21\end{array}$ & $\begin{array}{l}102 \pm 9 \\
127 \pm 14 \\
40 \pm 4 \\
51 \pm 8\end{array}$ & $\begin{array}{l}90 \pm 6 \\
92 \pm 10 \\
34 \pm 4 \\
36 \pm 5\end{array}$ \\
\hline $\begin{array}{l}\text { Delayed } \\
\text { return } \\
\text { obese }\end{array}$ & 4 & $\begin{array}{l}\text { Blood glucose } \\
\text { (mg per } 100 \mathrm{ml} \text { ) } \\
\text { Plasma insulin } \\
\text { (microunits per } \mathrm{ml} \text { ) }\end{array}$ & $\begin{array}{l}64 \pm 7 \\
90 \pm 7 \\
26 \pm 1 \\
25 \pm 1\end{array}$ & $\begin{array}{l}127 \pm 9 \\
35 \pm 7\end{array}$ & $\begin{array}{l}117 \pm 14 \\
168 \pm 11^{\mathrm{a}} \\
50 \pm 4 \\
51 \pm 16\end{array}$ & $\begin{array}{l}193 \pm 12 \\
51 \pm 12\end{array}$ & $\begin{array}{l}116 \pm 13 \\
209 \pm 11^{b} \\
62 \pm 8 \\
78 \pm 24\end{array}$ & $\begin{array}{l}116 \pm 6 \\
180 \pm 8 b \\
87 \pm 6 \\
90 \pm 31\end{array}$ & $\begin{array}{l}89 \pm 9 \\
139 \pm 12^{a} \\
69 \pm 14 \\
56 \pm 11\end{array}$ \\
\hline
\end{tabular}

1 Quoted as means \pm S.E.M.

a $P<0.05$

b $P<0.01$

c $P<0.001$.

Table 4. Appearance of "diabetes" according to various eriteria over the 5 year follow up period

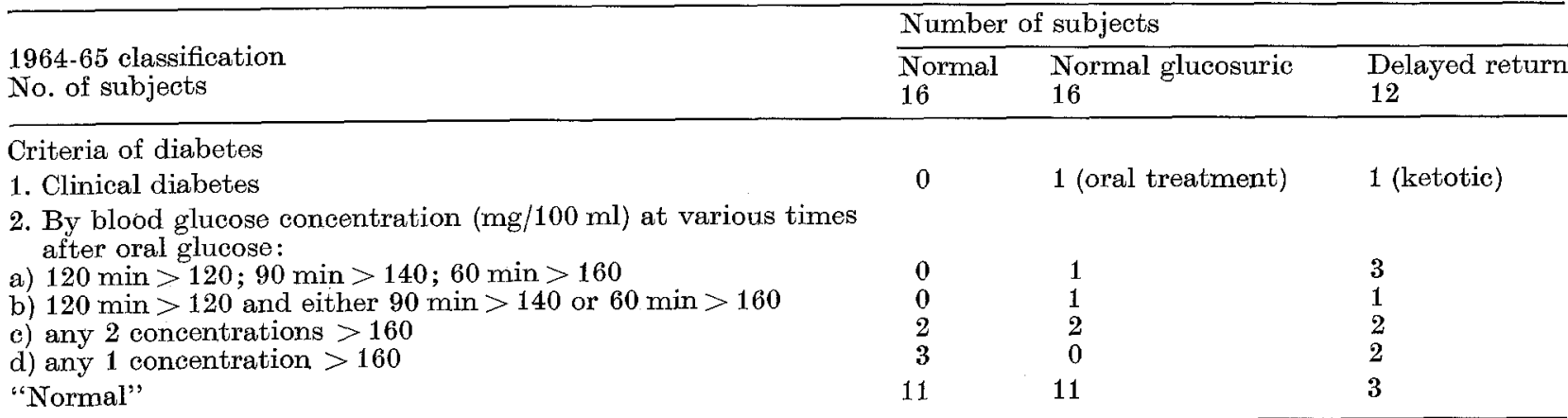

Table 5. Deterioration of glucose tolerance over the 5 year follow up period in the Arbroath subjects tested

\begin{tabular}{|c|c|c|c|c|c|c|}
\hline \multirow{3}{*}{ Criteria } & \multicolumn{6}{|c|}{ Classification in $1964-1965$} \\
\hline & \multicolumn{2}{|l|}{ Normal } & \multicolumn{2}{|c|}{ Normal glucosuric } & \multicolumn{2}{|l|}{ Delayed return } \\
\hline & non obese (8) & obese $(7)$ & non obese $(6)$ & obese $(9)$ & non obese $(7)$ & obese (4) \\
\hline $\begin{array}{l}\text { Change in area under the } \\
\text { glucose curves (arbitrary } \\
\text { units) }\end{array}$ & $29.8 \pm 6.6^{\mathrm{b}}$ & $20.1 \pm 9.4$ & $16.3 \pm 5.0^{\mathrm{a}}$ & $12.4 \pm 6.8$ & $8.4 \pm 7.7$ & $42.3 \pm 6.3^{\mathrm{b}}$ \\
\hline $\begin{array}{l}\text { Increase in } 120 \text { min blood } \\
\text { glucose concentration }\end{array}$ & $-0.9 \pm 7.5$ & $2.9 \pm 8.7$ & $33.6 \pm 7.8^{\mathrm{b}}$ & $22.7 \pm 7.8^{\mathrm{a}}$ & $3.4 \pm 11.6$ & $49.3 \pm 7.9 \mathrm{~b}$ \\
\hline
\end{tabular}

Results expressed as mean \pm S.E.M. of the differences calculated for each individual.

The numbers of individuals tested are indicated in parenthesis. 
in the plasma insulin concentration of the subjects with delayed return, whether they were obese or nonobese in 1964-65, although the increase in the area under the insulin curve of the non-obese group was significant $(p<0.05)$.

NORMAL (16)
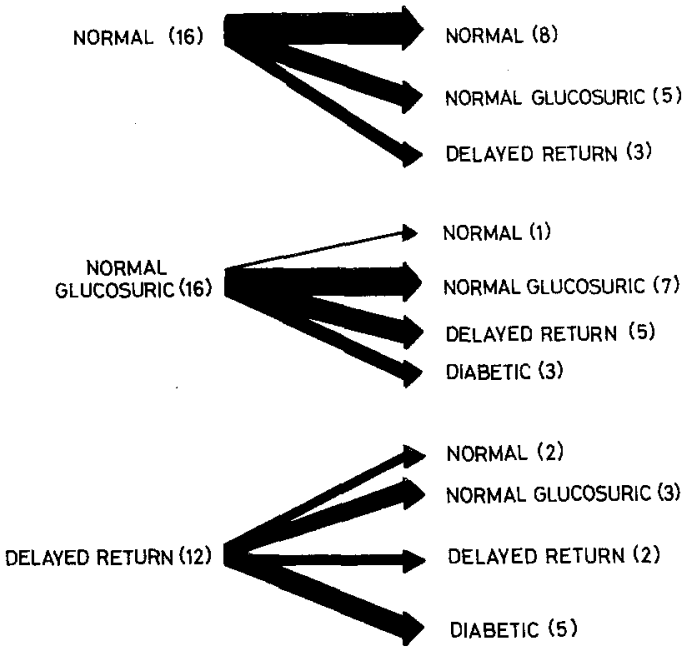

Fig. 2. Change in classification of results of oral glucose tolerance tests from that in 1964-65 (on left) to that in 1969-70 (on right). The thickness of the arrows is proportional to the percentage of the group undergoing any particular change, the absolute numbers are given in parenthesis. For definition of groups see text

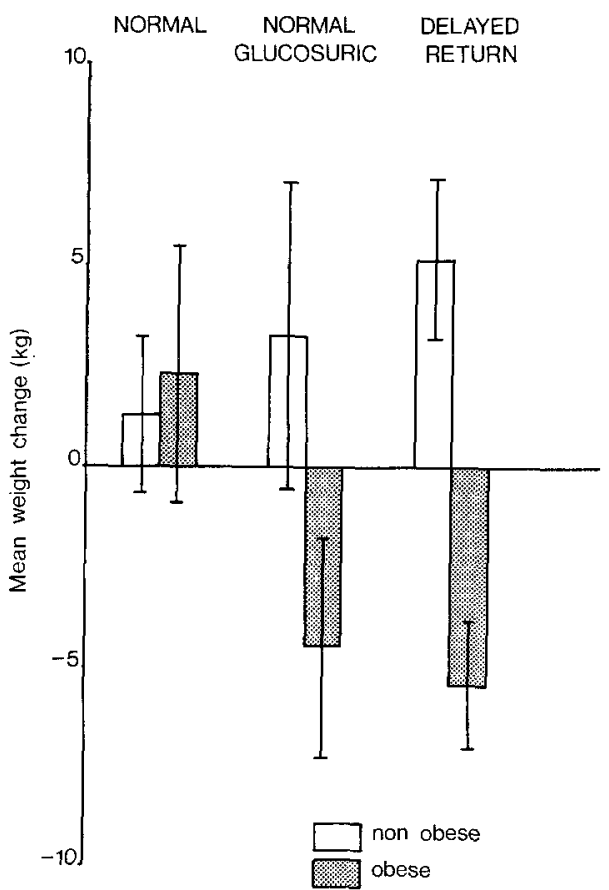

Fig. 3. Mean \pm S.E.M. weight changes observed over the five year follow up period plotted according to the classification of the subjects in 1964-65

\section{Discussion}

\section{Reproducibility of Previous Findings}

The pattern of observations remained remarkably consistent between the two studies, lending support to their general significance. Non-obese subjects with normal glucose tolerance and glucosuria continued to show an exaggerated, early rise in plasma insulin concentration following oral glucose, despite venous plasma glucose concentrations somewhat lower than the normal subjects. The plasma insulin response to oral glucose in subjects showing delayed return of the plasma glucose to the fasting concentration was again found to be delayed and sustained.

Aetiology of Diabetes. 1. Definition of diabetes. A number of different criteria are used currently for the arbitrary definition of "diabetes" from the results of an oral glucose tolerance test. Most of these criteria place greatest emphasis on the blood glucose concentrations towards the end of the test. From the results in Tables 4 and 5 it can be seen that this emphasis could also be justified in terms of the present study, since it gave the clearest subsequent separation between previously normal and abnormal subjects. The present results show that an increase in the area under the glucose curve and an increase in the $120 \mathrm{~min}$ blood giucose concentration are not different ways of expressing the same deterioration of glucose tolerance. These two indices were significantly pasitively correlated $(p<$ 0.05 ) only in the normal subjects, but were negatively, although insignificantly, correlated in the subjects with delayed return.

2. Role of obesity. Obesity is associated with insulin resistance. One possible cause for the appearance of diabetes over the 5 year follow-up period of this study would be excessive weight gain. If the weight changes over the 5 year interval were calculated according to the glucose tolerance in 1969-70 (Fig. 4) exactly the opposite was observed. There was an increasing tendency to loss of weight the worse the glucose tolerance, the mean weight loss being significant in the obese diabetic group $(<0.05)$. Further support for this relationship of weight change and glucose tolerance was obtained when the results of all the subjects were tested for a correlation between weight change and change in the $120 \mathrm{~min}$ blood glucose concentration. In every group, obese or non-obese, the correlation was negative and the pooled results gave a correlation coefficient of $-0.47(p<0.01)$. Subjects who were non-obese and showed delayed return of the blood glucose concentration in 1964-65 uniformly gained weight and showed a significant increase in the area under the plasma insulin curve. This finding is of considerable interest in relation to the connection between obesity and diabetes. Several years ago, Seltzer et al. [12] drew attention to symptomatic, spontaneous hypoglycaemia as an early manifestation of diabetes. From this, they also deduced the delayed rise of plasma insulin concentration after oral glucose, which is 
now recognised to be commonly associated with diabetes. They argued that hyperinsulinism late in the glucose tolerance could lead to hypoglycaemia. Our previous results [5] have shown that this pattern of insulin release may be found in non-diabetics, without a strong family history of diabetes, by selecting individuals with what we have defined as "delayed return" in their glucose tolerance. This pattern of insulin release might have important effects on such nondiabetic, non-obese individuals. Hypoglycaemia is even more likely in this situation and might lead to increased appetite, increased carbohydrate intake and weight gain. Thus a lag in insulin secretion in a normal person could predispose to obesity. The frequently observed connection between obesity and diabetes may not, therefore, only reflect the decreased insulin sensitivity due to obesity, but may also be the result of an. identical and predisposing abnormality of insulin release.

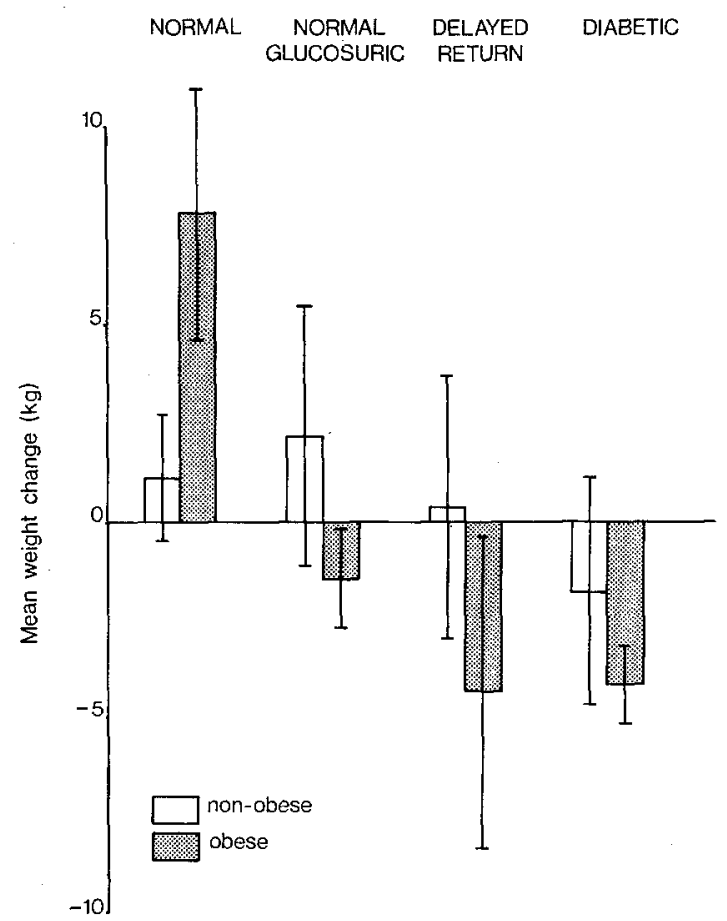

Fig. 4. Mean \pm S.E.M. weight changes observed over the five year follow up period plotted according to the classification of the subjects in $1969-70$

3. Plasma insulin. Most studies attempting to define changes in plasma insulin concentration in prediabetes have used individuals genetically predisposed to diabetes. The validity of this approach has been questioned [10]. As far as we are aware, no previous attempt has been made to study a sample of a normal population prospectively to determine the pattern of changes in plasma insulin concentration after oral glucose which occur in individuals prior to the onset of diabetes. It has been suggested that prediabetics have a (genetically determined) delayed rise in plasma in- sulin in response to glucose [2]. The results of the present study show that individuals with this type of insulin secretion are indeed those most likely to develop diabetes later. There was a highly negative correlation coefficient of $0.93(0.1>p>0.05)$ between the 1964-65 $30 \mathrm{~min}$ insulin: glucose ratio and the increase in 120 min blood glucose concentration after 5 years in the obese subjects with delayed return. Furthermore, the only individual to develop severe ketotic diabetes during the five year follow up period had in 196465 the flattest insulin response of all the 78 subjects tested (Fig. 5). It must be recognised that there is a certain inevitability about this finding which is the result of the definition of diabetes. We have shown that
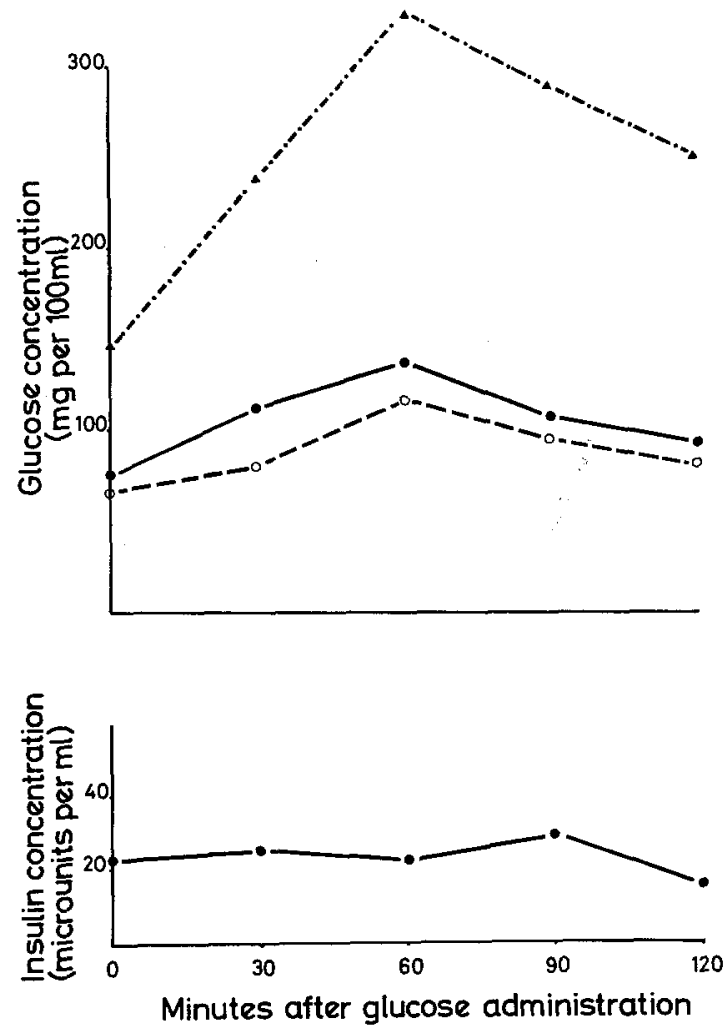

Fig. 5. Results of serial 50 g oral glucose tolerance tests on the one subject studied in 1964-65 who subsequently developed diabetic ketosis (1969). $0 \ldots \ldots$. $1962, \longrightarrow$ results in $1964, \mathbf{A} \cdot-\cdot \cdot \cdot-\mathbf{\Delta}$ results in 1969

people with delayed return have a lag in insulin output as judged by insulin concentration in peripheral plasma. Since the commonest definition of mild diabetes could be termed "severe delayed return" and since glucose tolerance deteriorates with ageing, it is inevitable that the delayed return group should produce "diabetes" in time. Diabetes however does not arise exclusively from subjects with this defect. Diabetes, both clinical and asymptomatic, arose from the obese "normal glucosuric" subjects, who appear to have normal or supranormal initial insulin responses in com- 
parisons with the obese normal subjects. The initial insulin response was not, however, higher than that of the non-obese glucosuric subjects, as might have been expected as a result of their obesity. Elevated insulin responses to oral glucose in genetic renal glucosuria have been described by Luyckx and Lefebvre [9], but the status of renal glucosuria as a prediabetic phenomenon remains controversial. In a five year follow up study, the Birmingham Diabetes Survey Working Party [1] reported that renal glucosuria was an innocent peculiarity, but that "lag storage" curves were converted in a significant number to a diabetic abnormality. It is likely that the normal glucosuries of the present study resemble the Birmingham "lag storage" group, since they showed elevated venous blood glucose concentrations 30-60 min after glucose and it is likely that their capillary glucose concentrations (as measured in the Birmingham survey) would have been considerably higher. For the same reason the statement that their insulin response was normal or supranormal must be qualified by the lack of information concerning the arterial glucose concentration and its relationship to the insulin response. It remains possible that the normal glucosuric subjects had an insulin response which was low relative to very high arterial glucose concentrations.

If the main factor determining the deterioration of glucose tolerance was deterioration of the capacity for insulin secretion rather than a constant defect of secretion on a background of changing sensitivity, then the change in insulin release over the five year period might be more important than the initial pattern of insulin release in 1964-65. The five year changes in insulin release for all subjects were expressed as changes in the absolute concentration at $30 \mathrm{~min}$, or changes in the $30 \mathrm{~min}$ insulin: glucose ratio, or changes in the area under the insulin curve. The obese subjects with delayed return showed the highest correlation coefficient $(-0.84)$ between the changes in the 30 min insulin concentration and that in the $120 \mathrm{~min}$ glucose concentration over the 5 year period. This suggested that further deterioration of the early insulin response to glucose could only have been an important factor determining the loss of glucose tolerance in this group. The small number of subjects in this group prevents a definite conclusion on this mechanism as it relates to the obese subjects with delayed return. Otherwise, neither this index nor any of the other indices of deterioration of insulin production were highly correlated with the deterioration of glucose tolerance in any group (as judged by an increase in the glucose concentration at $120 \mathrm{~min}$ ).

No satisfactory index of insulin sensitivity can be derived from the present results. The possible role of insulin resistance was assessed by assuming that a high insulin concentration at $120 \mathrm{~min}$ in the first test reflected a poor response to endogenous insulin. A significant $(p<0.01)$ positive correlation between this value and the 5 year change in the glucose concentra- tion at $120 \mathrm{~min}$ was found in the obese normal glucosuric subjects. This finding is consistent with insulin resistance being more important than insulin deficiency in determining the deterioration of glucose tolerance in this group.

Acknowledgements. We are grateful to the British Diabetic Association for research grants and to Burroughs Wellcome Research Laboratories, Beckenham, for the gift of ox insulin and rabbit anti-(guinea-pig serum) antiserum. The insulin assays were carried out in the Department of Biochemistry, University of Cambridge, and we are grateful to the Head of the Department, Professor Sir Frank Young for the facilities and encouragement which he provided at that time. Skilled technical assistance was provided by Mrs. M. Wisbey.

\section{References}

1. Birmingham Diabetes Survey Working Party. Fiveyear follow-up report on the Birmingham diabetes survey of 1962 . Brit. med. J. 1970 III, $301-305$

2. Cerasi, E., Efendić, S., Luft, R.: Dose-response re. lation between plasma-insulin and blood-glucose levels during oral glucose loads in prediabetic and diabetic subjects. Lancet $\mathbf{1 9 7 3} \mathrm{I}, 794$

3. Danowski, T.S., Lombardo, Y.B., Mendelsohn, L.B., Corredor, D.G., Morgan, C.R., Sabeh, G.: Insulin patterns prior to and after onset of diabetes. Metabolism 18, 731 - 740 (1969)

4. Hales, C.N.: Plasma levels of glucose, non-esterified fatty acid glycerol and insulin, four years before the onset of diabetic ketosis. Lancet 1967 II, 389-390

5. Hales, C.N., Greenwood, F.C., Mitchell, F.L., Strauss, W.T.: Blood-glucose, plasma-insulin and growth hormone concentrations of individuals with minor abnormalities of glucose tolerance. Diabetologia 4, 73-82 (1968)

6. Jackson, W.P.U., van Mieghem, W., Keller, P.: Insulin excess as the initial lesion in diabetes. Lancet 1972 I, $1040-1044$

7. Johansen, K.: Mild carbohydrate intolerance developing into classic juvenile diabetes. Acta med. scand. 189, $337-339$ (1971)

8. Fajans, S.S., Floyd, J.C., Jr., Conn, J.W., Pek, S.: The course of asymptomatic diabetes of children, adolescents and young adults. In: Early Diabetes, 377-384, (Eds. Camerini-Dávalos, R., Cole, H.S.). New York: Academic Press 1970

9. Luyckx, A., Lefebvre, P.: Glycosurie rénale et insulinémie, a propos d'une observation familiale. Ann. Endocrinol. 28, 141-145 (1967)

10. Pyke, D.A., Cassar, J., Todd, J., Taylor, K.W.: Glucose tolerance and serum insulin in identical twins of diabetics. Brit. med. J. 1970 IV, $649-651$

11. Rull, J.A., Conn, J.W., Floyd, J.C., Jr., Fajans, S.S.: Levels of plasma insulin during cortisone tolerance tests in "non-diabetic" relatives of diabetic patients. Diabetes 19, 1-10 (1970)

12. Seltzer, H.S., Fajans, S.S., Conn, J.W.: Spontaneous hypoglycaemia as an early manifestation of diabetes mellitus. Diabetes 5, 437-440 (1956)

13. Tattersall, R.B., Pyke, D.A.: Diabetes in identical twins. Lancet 1972 II, 1120-1125

14. Yalow, R.S., Berson, S.A.: Immunoassay of endogenous plasma insulin in man. J. clin. Invest. 39, 1157-1174 (1960)

Prof. Dr. C.N. Hales

Dept. of Medical Biochemistry

The Welsh National School of Medicine

Heath Park

Cardiff CF 44 XN, Great Britain 